\title{
The relationship of ambiguity tolerance and personality traits of youth in a transitive society
}

\author{
Zhanna Kara $^{1, *}$ and Liudmila Kruteleva ${ }^{1}$ \\ ${ }^{1}$ Southern Federal University, 116, Dneprovsky Pereulok, office. 402, Rostov-on-Don, 344065, \\ Russia
}

\begin{abstract}
The relevance of the topic is determined by the study of human personality and the quality of the existence in the world. It is necessary to study the ambiguity tolerance of young people for understanding the psychology of the future society. The purpose of the research is to reveal correlations of ambiguity tolerance and personality traits of young people under present-day conditions which are characterized as high-speed, rapidly changing, and unstable. Materials and methods: analysis of scientific literature on the research problem, testing, qualitative and quantitative methods of empirical data processing, including statistical processing of the obtained data, meaningful interpretation of the results. Results and discussion: The correlations between the parameters of ambiguity tolerance and personality traits of young people (male and female samples) have been revealed. There are negative correlations between the components of anxiety and ambiguity tolerance in the male sample, and positive correlations between ambiguity tolerance and personality traits in the female sample.
\end{abstract}

\section{Introduction}

In the present-day world, where ambiguity acts as the basis of human existence, it is essential to be able to accept the reality and to adapt to it under the rapidly changing conditions.

Today the uncertainty principle is considered at the level of significance of the principle of determinism (V.P. Zinchenko [1] and T.V. Kornilova [2]).

There is a tendency to change the understanding of the world from the outgoing "stable", "predictable", "controlled" to "incomprehensible", "uncontrolled", "indeterminate", "unpredictable" and "ambiguous" to a greater extent.

As a result, there is a change of the current image of a human, values, meanings, the image of science (A.N. Leontiev, 2005) [3].

The ambiguity, in relation to a human, his relationship with the world around, is associated with the concept of tolerance. And this is no coincidence. The ambiguity tolerance is viewed as a significant aspect affecting all areas of the human life.

Young people who are at the beginning of the development of their personality, professional path, and life self-determination are faced with difficulties in the transition from obtaining competencies to finding their place in the profession and in life, in general. One of

\footnotetext{
*Corresponding author: kara_j@mail.ru
} 
the main factors directly related to ambiguity tolerance is a rapidly changing external environment.

The ambiguity tolerance has been studied by scientists for quite a long time. But, at the same time, there is a necessity to identify it to understand the way of the society development and changes in psychological states of a human. Therefore, the purpose of this study is to identify the relationship of ambiguity tolerance and personality traits of young people under the modern conditions of ambiguity in a city.

The object of the research: young people aged 18-26 (the method of random sampling was used).

Subject of research: ambiguity tolerance and personality traits of young people.

Hypotheses:

1. It is assumed that in the current situation of transitivity the ambiguity tolerance and personality traits of young people will have some correlations. These correlations will indicate the peculiarities of their image of the world which expressed in their specificity of interaction in the society at the present time.

2. It is assumed that the male and female samples will differ.

\section{Materials and methods}

The problem of ambiguity tolerance has attracted more and more attention lately. The number of studies devoted to various aspects of this topic is increasing. These aspects are understanding of ambiguity, characteristic features of behavior patterns, relationships of people, self-regulation. It seems important to us to investigate the ambiguity tolerance as a component of the image of the world of a person, as an inner filling of the personality, which has various external manifestations.

In studying the understanding of the image of the world it seems important to highlight such directions as:

- a mental representation of the external reality (environment) during cognitive activity (R. Levin, U. Neisser, J. Piaget, L. Postman, E. Frenkel-Brunswick, K. Shannon, M. Sheriff; A.G. Asmolov, A.N. Leontiev, V.V.Petukhov, S.D. Smirnov, etc.);

- $\quad$ an integral system of meanings, a personal meaning and a sensory fabric (E.Yu. Artemieva, G.A. Berulava, V.P. Zinchenko, V.E. Klochko, A.N. Leontyev, Yu.M. Lotman, V.V. Nalimov, V.F. Petrenko, S.L. Rubinstein, V.P. Serkin, V.N. Toporov, A.G. Shmelev, etc.);

- a subjective understanding of the reality, a human interaction with the reality (experience, connections, relationships) (K.A. Abulkhanova-Slavskaya, L.I. Antsiferova, G.A. Berulava, D.A. Leontiev, F.E. Vasilyuk, AB Naryshkin, S.L. Rubinstein, etc.);

- a cross-cultural direction, intuitive ideas about the reality of any subject (nation, ethnos, personality) (E.Yu. Artemyeva, A.K. Belousova, V.F. Vasilyuk, V.P. Zinchenko, V.E. Klochko, A.A. Leontiev, D.A. Leontiev, V.V. Petukhov, V.F. Petrenko, S.D. Smirnov, etc.).

The peculiarity of the concept of the image of the world includes a combination and a mixture of an abstract and sensory perception. The concept of the image of the world, built into the cognitive processes, complements and expands the images of perception $[3,4]$. At the same time, we can confirm that any person has got a need for a certain clearness in understanding his own "Self", the image of the world, and the surrounding reality. It is known that a person is not able to stay in a situation of uncertainty if he/she has some different mental deviations $[5,6]$. But the transience of developing events, situations, relationships, social positions creates a field of ambiguity around the person. A balance is needed. So, as a result, there is a need to study the ambiguity tolerance. 
G.M. Andreeva defines reality as a social instability with increased demands for activity [7]. D.A. Leontiev considers ambiguity as a property of life with the assumption that many people experience negative emotions. A person can make a choice limiting the uncertainty and turning it into a certainty. "The principle of life of self-determined subjects is to develop a partial certainty out of this uncertainty, to turn entropy into non-entropy, while realizing that there will still be a lot of uncertainty" [8]. Norton R.W. (1975) [9] distinguishes the categories of disclosure of the concept of ambiguity. They are inaccuracy, fragmentation; plurality of judgments; probability; absence of structuredness; lack of information; variability; inconsistency; incomprehensibility.

The first studies of ambiguity tolerance appeared in the process of studying individuality and based on considering characteristics of the cognitive style. Further research of this concept expands the scope of the studied area.

Today, there are several approaches to the concept of ambiguity tolerance: as a personality trait, as an attitude (socially specific), as a metacognitive process and as a skill [9]. The largest number of studies of the concept of ambiguity considers it through the prism of personality traits.

Let us note some general aspects in overcoming the ambiguity and the consequences arising from it. These include: an explanation of overcoming the ambiguity, a model of differentiation according to the ability to accept, an explanation of the mechanisms of overcoming, ways of developing tolerance.

It is important to note the introduction of the concept of ambiguity tolerance (E. FrenkelBrunswik, 1948) in works on ethnic problems (stereotypes, anti-Semitism). The inability and unwillingness of some people to "think in the context of probabilities", to change their mindset, and to seek authoritative opinions to refer to them, was revealed. E. FrenkelBrunswick considered the ambiguity tolerance as a basic personality trait, which was introduced into the theory of authoritarian personality. This fact made it possible to further study the ambiguity tolerance $[9,10]$.

E. MacDonald, S. Badner, V. Sidanius and other scientists developed the concept and the content of the ambiguity tolerance as a basic personality trait $[9,10]$. S. Badner considered the ambiguity tolerance as a tendency to perceive ambiguous situations as desirable under the condition that the ambiguity perceived by a person is considered by him as a kind of a threat and is defined as perception of ambiguous, controversial situations, as intolerance. It is interesting to note the thought by $\mathrm{D}$. McLain, who considers the ambiguity tolerance as a trait that is " $\ldots$ a range of reactions, from rejection to attractiveness, when perceiving unknown, complex, dynamically indefinite or contradictory stimuli..." [10].

Domestic researchers are also investigating the problem of the ambiguity tolerance. I.N. Leonov carried out a detailed analysis of the ambiguity tolerance in the historical context of the forming of the construct. He comes to the conclusion that most Western scientists define this phenomenon precisely as a personality trait that is stable in time and changeable depending on the acquired experience or personality activity [10].

D.A. Leontiev, exploring the leading condition for accompanying a person in a transitional period, determines the ambiguity tolerance as non-directiveness and nondeficiency of the professional position of a psychologist. He also examines the types of attitudes towards ambiguity in the context of intolerant and tolerant, which makes it possible to distinguish the following types: "active", "passive", "utilitarian" and a special "nondeficient" type. The essence of the "non-deficient" type includes the attitude to chaos, disorder, ambiguity as to the beginning of personality development [11].

According to O.A. Kondrashihin (2015), O.S. Vindeker (2016), A.Sh. Guseinov (2018), L.O. Pelepchuk (2019), I.V. Abakumova (2020) the ambiguity tolerance is a personality trait that allows the person to withstand the crisis manifestations associated with the uncertainty of the meaning foundations of one's own existence, which arise during the transition to a new 
identity. The ambiguity tolerance is considered by them in the form of a multilevel and multidimensional personal construct, which can be attributed to the "integral characteristics of the personality" [10 - 16].

Taking into account the given scientific points of view, we propose to consider the situation of the ambiguity tolerance precisely through the system of internal determinants of personality and contradictions that arise in them. And we offer the following understanding of the ambiguity tolerance: a situation of the ambiguity tolerance is a problematic situation that arises in the living space of an individual, which is not clearly determined either in ways of its solutions or in its final outcome.

The situational components of the display of the ambiguity tolerance are a lack of a life experience in relation to the current situation; a completion of a certain life stage and the emergence of a new one; a need to make a decision; a situation of a forced choice; distrust in information or its absence.

Thus, it is possible to generalize and highlight such personal characteristics of ambiguity tolerance as: an individual inclination in the emotional-volitional sphere of the personality, individual inclination in the cognitive sphere of the personality, individual self-regulation, and social-psychological attitude.

\section{Methods}

Further, the studied sample was determined, and the diagnostic material was selected.

We applied such methods as testing, methods of qualitative, quantitative and statistical data processing, and the meaningful interpretation of the results. The data processing included descriptive statistics methods and Spearman's rank correlation analysis.

The following techniques were reasonably chosen as diagnostic tools: Multiple Stimulus Types Ambiguity Tolerance Scale-I (McLain, validated by E.N. Osin) [17]; Individualtypological questionnaire (L.N. Sobchik) [18]. These techniques are standardized and validated.

Multiple Stimulus Types Ambiguity Tolerance Scale-I (McLain, validated by E.N. Osin) was chosen to measure the personality's tendency to the rigidly life regulation and to perception of complete information of what is happening, or to openness to ambiguity. The technique includes 5 subscales defined into 2 blocks. The technique allows us to determine the relationship between the personality traits of young people and situations of ambiguity.

To identify personal characteristics of young people, we used individual-typological questionnaire. The technique allows us to reveal features and accentuations of a person, its psychological state and the level of inadaptation.

\section{Results}

\subsection{Organization of the study}

The study involved 93 respondents aged 18-26, randomly selected, who are not related to each other. Research (data collection) was conducted with each person individually. It was assumed that excluding the team would provide an opportunity to receive more sincere answers of the respondents.

All the respondents were divided by gender into 2 groups. Group 1 comprised 45 males, and group 2 comprised 48 females. The average age of the respondents was 24.73 (group 1) and 21.08 (group 2). 
Spearman's rank correlation analysis allowed us to reveal correlations between the ambiguity tolerance and individual-typological features of personality of the respondents. The statistically significant correlations are represented in Tables 1 and 2.

\subsection{The results of group 1}

There is a high significant direct correlation between "attitude to novelty" and "extraversion" $\left(\mathrm{r}_{\mathrm{s}}=0,555, \mathrm{p} \leq 0,01\right)$; "attitude to novelty" and "spontaneity" ( $\left.\mathrm{r}_{\mathrm{s}}=0,747, \mathrm{p} \leq 0,01\right)$. There is a high significant inverse correlation between "attitude to novelty" and "introversion" $\left(\mathrm{r}_{\mathrm{s}}=-\right.$ $0,583, \mathrm{p} \leq 0,01)$; "attitude to novelty" and "sensitivity" ( $\left.\mathrm{r}_{\mathrm{s}}=-0,822, \mathrm{p} \leq 0,01\right)$; "attitude to novelty" and "anxiety" ( $\left.\mathrm{r}_{\mathrm{s}}=-0,486, \mathrm{p} \leq 0,01\right)$; "attitude to novelty" and "lability" $\left(\mathrm{r}_{\mathrm{s}}=-0,310\right.$, $\mathrm{p} \leq 0,01)$.

The revealed correlations may indicate that the representatives of the male sample more often manifest themselves as active, energetic, sociable, aggressive, striving for leadership. At the same time, in a situation of novelty the introversion can be displayed as sensitivity and orientation towards a strong personality and anxiety can be minimized by lability.

There is a high significant direct correlation between "attitude to uncertain situations" and "extraversion" ( $\left.r_{s}=0,470, p \leq 0,01\right)$. There is a high significant inverse correlation between "attitude to uncertain situations" and "introversion" $\left(\mathrm{r}_{\mathrm{s}}=-0,532, \mathrm{p} \leq 0,01\right)$. The correlations may indicate that the representatives of the male sample show tolerance in uncertain, unpredictable situations impulsively, aggressively, energetically from the position of the leader.

There is a high significant direct correlation between "Preference for ambiguity" and "extraversion" ( $\left.r_{s}=0,396, p \leq 0,01\right)$. There is a high significant inverse correlation between "Preference for ambiguity" and "introversion" $\left(\mathrm{r}_{\mathrm{s}}=-0,740, \mathrm{p} \leq 0,01\right)$; "Preference for ambiguity" and "sensitivity" $\left(\mathrm{r}_{\mathrm{s}}=-0,430, \mathrm{p} \leq 0,01\right)$; "Preference for ambiguity" and "anxiety" $\left(r_{s}=-0,449, p \leq 0,01\right)$. According to the findings it is possible to state that the revealed correlations indicate a desire of young men for risky behavior.

There is a high significant inverse correlation between "ambiguity tolerance" and "spontaneity" ( $\left.\mathrm{r}_{\mathrm{s}}=0,487, \mathrm{p} \leq 0,01\right)$; "ambiguity tolerance" and "extraversion". There is a high significant inverse correlation between "ambiguity tolerance" and "sensitivity" $\left(\mathrm{r}_{\mathrm{s}}=-0,528\right.$, $\mathrm{p} \leq 0,01)$; "ambiguity tolerance" and "introversion" ( $\left.\mathrm{r}_{\mathrm{s}}=-0,391, \mathrm{p} \leq 0,01\right)$.

There is a high significant inverse correlation between "attitude to complex tasks" and "introversion" $\left(\mathrm{r}_{\mathrm{s}}=-0,596, \mathrm{p} \leq 0,01\right)$; "attitude to complex tasks" and "anxiety" $\left(\mathrm{r}_{\mathrm{s}}=-0,470\right.$, $\mathrm{p} \leq 0,01)$.

Table 1. Spearman's rank correlation coefficients ( $\left.\mathrm{N}=45, \mathrm{p}<0,01^{* *}, \mathrm{p}<0,05^{*}\right)$, group 1.

\begin{tabular}{|c|c|c|c|c|c|c|c|c|}
\hline & $\begin{array}{c}\text { Extraver } \\
\text { sion }\end{array}$ & $\begin{array}{c}\text { Spontan } \\
\text { eity }\end{array}$ & $\begin{array}{c}\text { Aggressive } \\
\text { ness }\end{array}$ & $\begin{array}{c}\text { Rigid } \\
\text { ity }\end{array}$ & $\begin{array}{c}\text { Introver } \\
\text { sion }\end{array}$ & $\begin{array}{c}\text { Sensiti } \\
\text { vity }\end{array}$ & $\begin{array}{c}\text { Anxi } \\
\text { ety }\end{array}$ & $\begin{array}{c}\text { Labil } \\
\text { ity }\end{array}$ \\
\hline $\begin{array}{l}\text { Attitud } \\
\text { e to } \\
\text { novelty }\end{array}$ & $.555^{* *}$ & $.747^{* *}$ & .007 & .196 & $-.583^{* *}$ & $-.822^{* *}$ & $\begin{array}{c}- \\
.486^{*} \\
*\end{array}$ & $-.310^{*}$ \\
\hline $\begin{array}{l}\text { Attitud } \\
\text { e to } \\
\text { comple } \\
x \text { tasks } \\
\end{array}$ & $.332^{*}$ & $.360^{*}$ & .141 & -.012 & $-.596^{* *}$ & $-.324^{*}$ & $\stackrel{-}{.470^{*}}$ & .047 \\
\hline $\begin{array}{l}\text { Attitud } \\
\text { e to } \\
\text { uncerta } \\
\text { in } \\
\text { situatio } \\
\text { ns }\end{array}$ & $.470^{* *}$ & $.326^{*}$ & .203 & -.123 &.$- .532^{* *}$ & $-.295^{*}$ & $\begin{array}{c}- \\
.367^{*}\end{array}$ & .186 \\
\hline
\end{tabular}




\begin{tabular}{|c|c|c|c|c|c|c|c|c|}
\hline $\begin{array}{l}\text { Prefere } \\
\text { nce for } \\
\text { ambigu } \\
\text { ity }\end{array}$ & $.396^{* * *}$ & .252 & .183 & -.070 & $-.740^{* *}$ & $-.430^{* * *}$ & ${ }_{*}^{-}$ & .121 \\
\hline $\begin{array}{l}\text { Ambig } \\
\text { uity } \\
\text { toleran } \\
\text { ce }\end{array}$ & .276 & $.487^{* *}$ & .274 & .031 & $-.391^{\text {** }}$ & $-.528^{* *}$ &.${ }^{-} 3^{*}$ & -.070 \\
\hline $\begin{array}{l}\text { Overall } \\
\text { score }\end{array}$ & .128 & .114 & -.132 & -.073 & -.138 & -.196 & -.257 & -.260 \\
\hline
\end{tabular}

\subsection{The results of group 2}

There is a high significant direct correlation between "Attitude to novelty" and "extraversion" $\left(\mathrm{r}_{\mathrm{s}}=0,478, \mathrm{p} \leq 0,01\right)$.

There is a high significant direct correlation between "attitude to complex tasks" and "Spontaneity" $\left(\mathrm{r}_{\mathrm{s}}=0,458, \mathrm{p} \leq 0,01\right)$; "attitude to complex tasks" and "aggressiveness" $\left(\mathrm{r}_{\mathrm{s}}=0,622, \mathrm{p} \leq 0,01\right)$; "attitude to complex tasks" and "sensitivity" $\left(\mathrm{r}_{\mathrm{s}}=0,551, \mathrm{p} \leq 0,01\right)$; "attitude to complex tasks" and "anxiety" $\left(\mathrm{r}_{\mathrm{s}}=0,608, \mathrm{p} \leq 0,01\right)$.

There is a high significant direct correlation between "preference for ambiguity" and "aggressiveness" $\left(r_{s}=0,505, p \leq 0,01\right)$; "preference for ambiguity" and "anxiety" $\left(r_{s}=0,414\right.$, $\mathrm{p} \leq 0,01)$.

There is a high significant direct correlation between "ambiguity tolerance' and "Sensitivity" $\left(\mathrm{r}_{\mathrm{s}}=0,379, \mathrm{p} \leq 0,01\right)$.

There is no significant correlations between "attitude to complex tasks" and any scale of Individual-typological questionnaire.

Table 2. Spearman's rank correlation coefficients $\left(\mathrm{N}=48, \mathrm{p}<0,01^{* *}, \mathrm{p}<0,05^{*}\right)$, group 2 .

\begin{tabular}{|c|c|c|c|c|c|c|c|c|}
\hline & $\begin{array}{c}\text { Extraver } \\
\text { sion }\end{array}$ & $\begin{array}{c}\text { Spontan } \\
\text { eity }\end{array}$ & $\begin{array}{c}\text { Aggressive } \\
\text { ness }\end{array}$ & $\begin{array}{c}\text { Rigid } \\
\text { ity }\end{array}$ & $\begin{array}{c}\text { Introver } \\
\text { sion }\end{array}$ & $\begin{array}{c}\text { Sensiti } \\
\text { vity }\end{array}$ & $\begin{array}{c}\text { Anxi } \\
\text { ety }\end{array}$ & $\begin{array}{c}\text { Labil } \\
\text { ity }\end{array}$ \\
\hline $\begin{array}{l}\text { Attitud } \\
\text { e to } \\
\text { novelty }\end{array}$ & .144 & .028 & .093 & .108 & .130 & $.344^{*}$ & .197 & $.455^{\text {** }}$ \\
\hline $\begin{array}{l}\text { Attitud } \\
\text { e to } \\
\text { comple } \\
x \text { tasks }\end{array}$ & .272 & $.458^{* *}$ & $.622^{* *}$ & $.345^{*}$ & .198 & $.551^{k * *}$ & $.608^{*}$ & $.364^{*}$ \\
\hline $\begin{array}{l}\text { Attitud } \\
\text { e to } \\
\text { uncerta } \\
\text { in } \\
\text { situatio } \\
\text { ns } \\
\end{array}$ & .196 & .043 & .232 & -.129 & -.113 & .103 & .129 & -.081 \\
\hline $\begin{array}{l}\text { Prefere } \\
\text { nce for } \\
\text { ambigu } \\
\text { ity }\end{array}$ & $.351^{*}$ & $.321^{*}$ & $.505^{* *}$ & .251 & -.008 & $.285^{*}$ & $.414^{*}$ & .218 \\
\hline $\begin{array}{l}\text { Ambig } \\
\text { uity } \\
\text { toleran } \\
\text { ce }\end{array}$ & .095 & .120 & .126 & .182 & $.285^{*}$ & $.379^{* * *}$ & .193 & .203 \\
\hline $\begin{array}{l}\begin{array}{l}\text { Overall } \\
\text { score }\end{array} \\
\end{array}$ & $.444^{* * *}$ & $.415^{* *}$ & $.527^{* *}$ & $.351^{*}$ & .123 & $.443^{* *}$ & $\mathbf{. 5 0 1}_{*}^{*}$ & $.344^{*}$ \\
\hline
\end{tabular}


To prove the assumption of differences in the groups nonparametric U-Mann-Whitney test was used (Table 3).

According to the Mann-Whitney U-test (with continuity correction) the researched groups have got statistically significant differences in "attitude to novelty", "attitude to uncertain situations", and "ambiguity tolerance" ( $U_{\text {emp }}$ is less than critical values: $U_{\mathrm{cr}}=776, p \leq 0.01$ and $\mathrm{U}_{\mathrm{cr}}=865, \mathrm{p} \leq 0.05$ ) and it is more likely that the differences between the groups are significant. It means that the representatives of the male sample, in comparison with the representatives of the female sample, are characterized by a higher involvement in the existent situation, and they feel more comfortable to a greater extent. At the same time, the representatives of the female sample are more likely to keep up traditions.

Table 3. Statistically significant differences Mann-Whitney U-test $(\mathrm{p} \leq 0.05)$.

\begin{tabular}{|l|c|c|c|c|}
\hline & & Middle rank & & \\
\hline & Group 1 & Group 2 & U Mann-Whitney & $\begin{array}{c}\text { Statistical } \\
\text { significance level } \\
\text { (p) }\end{array}$ \\
\hline $\begin{array}{l}\text { Attitude to } \\
\text { novelty }\end{array}$ & 58.27 & 36.44 & 573.000 & .000 \\
\hline $\begin{array}{l}\text { Attitude to } \\
\text { uncertain } \\
\text { situations }\end{array}$ & 56.17 & 38.41 & 667.500 & .001 \\
\hline $\begin{array}{l}\text { Ambiguity } \\
\text { tolerance }\end{array}$ & 58.90 & 35.84 & 544.500 & .000 \\
\hline
\end{tabular}

\section{Discussion}

The obtained results designate that young men are characterized by a manifestation of a positive attitude towards new things, a propensity for active contacts and interaction with other people, a demonstration of flexibility in a situation of uncertainty, and an appeal to internal resources. They are more inclined to take action, can stand uncertain situations, to be tolerant to various situations. They perceive ambiguity as a strive for activity. At the same time, immersion in oneself, sensitivity for external circumstances reduces anxiety, and vice versa.

The comparison of the mean values, presented by E.V. Osin, and the obtained findings revealed lower indices of ambiguity tolerance in all scales except the scale of "attitude to novelty". This is due to the external situation of ambiguity, which influences the transformation of the internal image of the world.

The representatives of the female sample are characterized by a manifestation of a positive attitude to the new things in a situation of novelty. This attitude to novelty is associated with a social component. The attitude to complex tasks is connected with aggressiveness, sensitivity, anxiety. This can be explained by the appeal to their inner world, with increased emotiveness, flexibility, instability in motivation, and demonstrativeness. A higher level of scales indicates the desire of women for asserting themselves, activity, independence. And at the same time, there is a tendency to avoid ambiguity. The revealed high significant direct correlation between "attitude to complex tasks" and "spontaneity" can be explained by self-expression, openness, aggressiveness in relation to new complex tasks. The correlations between "attitude to complex tasks" and "sensitivity", "attitude to complex tasks" and "anxiety" indicate the manifestation of tolerance towards difficult tasks through the orientation towards a more significant person, authority. This displays in forming a weak type, conformity, fasten to women a certain stereotype of behavior. 


\section{Conclusion}

1. It is found that in a situation of uncertainty, the ambiguity tolerance and personality traits have significant direct correlations in the female sample, and significant direct and inverse correlations in the male sample.

2. In the female sample, an increase in the level of ambiguity tolerance was revealed in relation to such personality traits as "spontaneity", "aggressiveness", "anxiety". Thus, there is a tension in the psychological state of the respondents.

3. The differences between the groups (male, female) were revealed according to the parameters of "attitude to novelty", "attitude to uncertain situations", "ambiguity tolerance". 4. It was found that in a situation of uncertainty, the personality traits influence the development of ambiguity tolerance.

\section{References}

1. V.P. Zinchenko, Uncertainty tolerance: news or psychological tradition. Psychology issues 6, 3-20 (2007)

2. T.V. Kornilova, E.M. Pavlova, Psychological-Educational Studies 11(1), 107-117 (2019) https://doi:10.17759/psyedu.2019110109.

3. A.N. Leontiev, A.R. Luria, Journal of Russian and East European Psychology 43(4), 34 (2005)

4. R.M. Shamionov, A.V. Grigoryev, International Journal of Cognitive Research in Science, En-gineering and Education (IJCRSEE) 7(1), 15-20 (2019) https://doi.org/10.5937/ijcrsee1901015S

5. E.T. Sokolova, Moscow University Bulletin. Series 14: Psychology 2, 37-48 (2012) http://msupsyj.ru/en/

6. A. Ussenova, et al., International Journal of Cognitive Research in Science, Engineering and Education (IJCRSEE) 8(2), 15-26 (2020) http://doi: 10.5937/IJCRSEE2002015U

7. G.M. Andreeva, Psychology issues 3, 33-43 (2013)

8. D.A. Leontiev, Psikhologicheskie Issledovaniya 8(40), 2 (2015) http://psystudy.ru

9. R.W. Norton, Journal of Personality Assessment 39(6), 607-619 (1975)

10. I.N. Leonov, Bulletin of the Udmurd University 4, 43-52 (2014)

11. D.A. Leontiev, Psychological research 8(40), 2 (2015) http://psystudy.ru

12. A.Sh. Guseinov, Society: sociology, psychology, pedagogy 12, 127-130 (2018) https://doi.org/10.24158/spp.2018.12.21

13. O.A. Kondrashihina, Perspectives of Science \& Education 5(17), 83-87 (2015)

14. O.S. Vindeker, M.V. Klimenskikh, Russian psychological journal 13(3), 107-122 (2016) https://doi.org/10.21702/rpj.2016.3.7

15. I.V. Abakumova, M.V. Godunov, A.V. Grishina, International Journal of Cognitive Research in Science, Engineering and Education (IJCRSEE) 8(2), 53-58 (2020) https://doi: 10.5937/IJCRSEE2002053A

16. L.O. Pelepchuk, Simbirsk Scientific Bulletin 4(38), 37-40 (2019)

17. D.A. Leontiev, Diagnosis of uncertainty tolerance. D. MacLane scales (Smysl, M., 2016)

18. L.N. Sobchik, Psychodiagnostics in medicine. A practical guide (Borges, M., 2007) 